\title{
Laryngotracheoesophageal cleft type 2
}

INSERM

\section{Source}

INSERM. (1999). Orphanet: an online rare disease and orphan drug data base.

Laryngotracheoesophageal cleft type 2. ORPHA:93939

Laryngo-tracheo-esophageal cleft (LC) type 2 is a congenital respiratory tract anomaly characterized by a cleft extending below the vocal folds into the cricoid cartilage, with swallowing disorders and lung infections. 